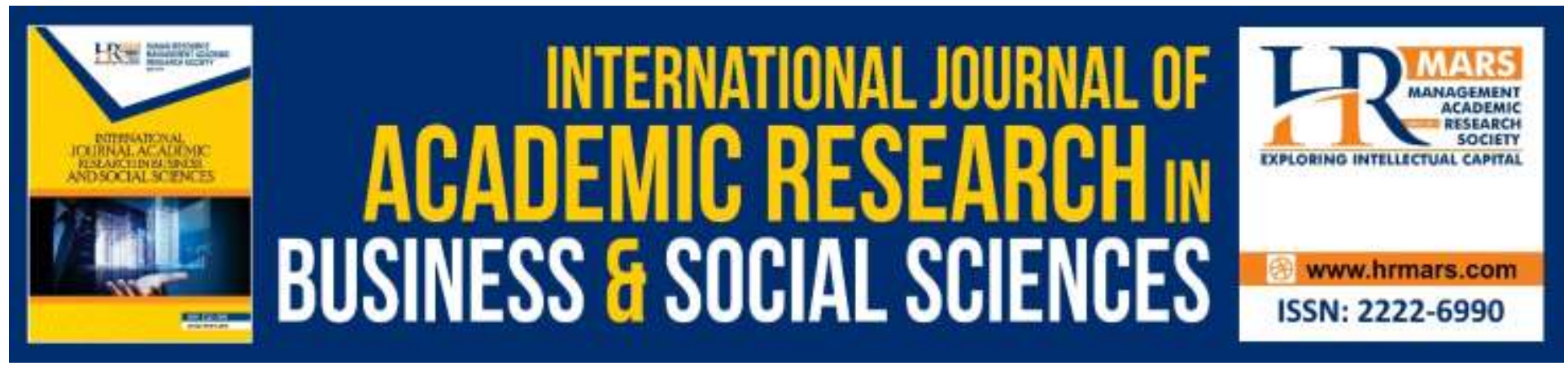

\title{
Issues and Trends of Portfolio Diversification
}

\section{Aminah Shari, Fauziah Mahat, Ahmed Mohamed Dahir}

To Link this Article: http://dx.doi.org/10.6007/IJARBSS/v9-i11/6652

DOI: 10.6007/IJARBSS/v9-i11/6652

Received: 10 October 2019, Revised: 30 October 2019, Accepted: 03 November 2019

Published Online: 17 November 2019

In-Text Citation: (Shari, Mahat, \& Dahir, 2019)

To Cite this Article: Shari, A., Mahat, F., \& Dahir, A. M. (2019). Issues and Trends of Portfolio Diversification. International Journal of Academic Research in Business and Social Sciences, 9(11), 1237-1243.

Copyright: (C) 2019 The Author(s)

Published by Human Resource Management Academic Research Society (www.hrmars.com)

This article is published under the Creative Commons Attribution (CC BY 4.0) license. Anyone may reproduce, distribute, translate and create derivative works of this article (for both commercial and non-commercial purposes), subject to full attribution to the original publication and authors. The full terms of this license may be seen at: http://creativecommons.org/licences/by/4.0/legalcode

Vol. 9, No. 11, 2019, Pg. 1237 - 1243

Full Terms \& Conditions of access and use can be found at http://hrmars.com/index.php/pages/detail/publication-ethics 


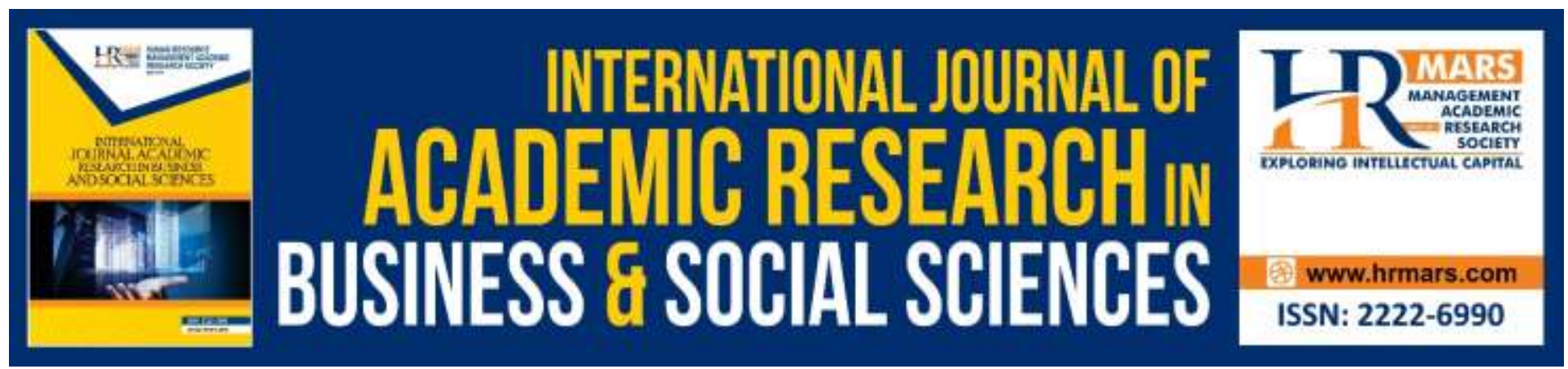

\title{
Issues and Trends of Portfolio Diversification
}

\author{
Aminah Shari, Fauziah Mahat, Ahmed Mohamed Dahir \\ Department of Accounting and Finance, Faculty of Economics and Management \\ Universiti Putra Malaysia, Serdang, Selangor, Malaysia
}

\begin{abstract}
The concept of diversification has been a great importance in risk management and investment decision making in the capital market. The purpose of this paper is to examine the issues and trends of diversification of risk on capital market. In addition, the paper highlight some of the latest trends and developments in the area namely multi-asset class investment and comovement of risk and return. Moreover, in light of the basis of modern capital market theory developed by Harry Markowitz, the paper review some of the approaches developed to address the challenges encountered when using diversification strategy in practice, including the portfolio choice problem, alternative assets class and time-varying volatility assessment.
\end{abstract}

Keywords: Diversification, Portfolio Choice, Capital Market, Investment Decision, Finance

\section{Introduction}

Capital markets around the world, and particularly in the emerging market, experienced rapid globalization and internationalization due to the development of financial securities instruments. Hence, the tradeoff between risk and returns plays an important role in making investment decisions. Investors attempt to reduce the risk of their portfolio by diversifying their asset holdings so that there are sufficiently unrelated to each other. In order to achieve portfolio diversification benefits, the tradeoff between risks and returns plays an important role in making investment decisions (Anand, Li, Kurosaki, and Kim, 2016). Investors attempt to reduce the risk of their portfolio by diversifying their asset holdings so that they are sufficiently unrelated to each other. Also, it is possible that investors would allocate a substantial portion of their funds toward risky assets instead of non-risky assets or the combination of risky and non-risky assets in order to seek a higher return. Therefore, it is important for investors to understand the correlation between assets in capital market for asset allocation strategies, risk management, pricing and hedging activities. In a study by Cascino (2017) has proven the important of correlation as a fundamental input for asset allocation decisions as it determines the diversification benefits of bonds relative to equities within an investment portfolio. Consistent with portfolio theory, 
investing in less correlated assets will result in a greater diversification gains (Ahmed and Huo, 2018)

Nonetheless, after recent crisis, a fundamental question has been posed by investors, regulators and academic researchers particularly the questions is about whether a risk-averse investors can improve their risk-return profile by expanding the capital market investment opportunity set to include risky and non-risky assets namely commodity, equity, mutual funds, ETF and treasury bills and money market funds (Cotter, Eyiah-donkor, and Potì, 2017). It is also triggered the interest of them in examining asset allocation strategies for effective diversification of risk. Diversification of risk across the region was difficult to achieve as they diversify into different economic sectors (Sukumaran, Gupta, and Jithendranathan, 2015).

The purpose of this paper is to review empirical studies on the issues and trends of diversification of risk on capital market investment and show other direction for future research. This would provide additional insight to investors particularly retail and institutional investors, financial institutions, analysts to assess the future trend of the market as well as a useful guideline for portfolio formation and investment decisions.

It is also can be better used to understand investment decisions in a meaningful way enable considerable insights into the role of mixed-asset in optimal portfolio. This would result in increased relevance for retail investors or institutional investors and industry player namely portfolio managers to improve the return on investment by identifying the best securities that will enhance the risk-return profile of the portfolio. According to the statistics, the risky assets (equities) portfolio remains the largest contributor to the institutional investor. Despite, institutional portfolio managers namely mutual funds, insurance companies, bank trusts, pension funds, and hedge funds, they are playing a growing role in capital markets around the world.

The article is organized as follows. Section 2 presents the theoretical insight of portfolio diversification. Section 3 describes the issues of diversification of risk on capital market. Section 4 describes the trends of diversification of risk on capital market and section 5 concludes.

\section{Theoretical Insight on Portfolio Diversification}

Markowitz's (1952) portfolio theory is one of the most important theoretical developments in finance. The concept of portfolio diversification and efficiency develop by Markowitz are the basis of modern capital market theory. The pioneering works of Harry Markowitz' and James Tobin resulted in the famous Mean-Variance (M-V) model, which demonstrates that the reduction in risk from portfolio diversification depends on correlations among return distributions of individual securities. Even though diversification among risky assets available in a particular country leads to risk reduction, the potential is rather limited due to the generally high correlations within an economy. This suggests the possibility of further risk reduction through international portfolio diversification. 
Since the seminal paper of Markowitz (1952) several studies have explored the possibility of building an optimal portfolio that reduces risk (Kroner and $\mathrm{Ng}, 1998$ ). According to classical finance theory, an investor's risk attitude determines the optimal portfolio from the set of efficient portfolios, that is, from the capital market line (Tobin, 1958). Greater risk tolerance will result in the choice of higher volatility, which is compensated for by a higher expected return (Ehm, Kaufmann, and Weber, 2014).

\section{Issues of Diversification of Risk on Capital Market Risk-averse Investor's Portfolio Choice Problem}

After the recent crisis, a fundamental question has been posed by investors, regulators and academic researchers particularly the questions is about whether risk-averse investors can improve their risk-return profile by expanding the investment opportunity set to across various asset classes (Cotter, Eyiah-donkor, and Poti, 2017). It is also triggered the interest of them in examining asset allocation strategies for effective diversification of risk. Over the past decades, diminishing benefits resulting from diversification has been a hot issue for investors and researchers.

\section{Alternative Assets Gain more Diversification Opportunities}

Much of the research in this area has been restricted to conventional financial assets, namely stocks and bonds (Demirer, 2016). From investment perspective, debt securities are essential part of diversification strategy and several studies focusing the relationship between stock and bond market in the context of portfolio diversification (Demirer, 2016). Furthermore, recent evidence suggests that Islamic bonds are negatively correlated with global stocks, particularly during periods of high volatility (Demirer, 2016), while Hammoudeh, Mensi, Reboredo, and Nguyen (2014) find that Islamic stocks exhibit significant dependence with major global equity markets in the U.S., Europe and Asia. It can thus be argued that Islamic bonds would exhibit negative correlation with global equity markets, further motivating a study of diversification benefits of these securities for global equity portfolios. Therefore, given these recent findings in the Islamic finance literature, a natural research question is whether these securities could be a viable alternative to conventional bonds as a diversification tool for stock portfolios.

\section{Time-Varying Volatility Assessments}

The term correlation or familiar known as co-movement is a fundamental aspect of asset allocation decisions. The co-movement of risks and returns in the stock markets has significant implications on portfolio diversification (Marfatia, 2017). In particular, the co-movement of risk has been the main issue among investors, regulators and academic researchers. In addition, it is important to distinguish the time horizon of investment due to the dynamics that govern shortterm investment risks that may be very different from long-term investment risks for the planning of investment strategies and portfolio diversification strategy (Candelon, Piplack, and Straetmans, 2008). 
Literature review on the co-movement of stock market returns has undergone significant changes across time can be found, for instance in (Bekaert and Harvey, 1995). One of the limitations in this strand of literature is that it does not differentiate the co-movement of risks based on short-term and long-term investment horizons. Much of the prior research documents the co-movement of stock market based on their time-domain but not on the frequency domain of integration. Those studies that undertake a time frequency domain approach into the analysis are mainly limited to the returns level such as (Bouri, Gupta, Hosseini, and Lau, 2018; Kim and Sun, 2017; Mazouz, Mohamed, and Saadouni, 2016).

\section{Trends of Diversification of Risk on Capital Market Diversification of Risk through Multi-Asset Class Investment}

Podkaminer, Tollette, and Siegel (2019) suggested a multi-asset class investment to search for optimal portfolios by tackle the shock to economic growth. Mimouni, Charfeddine, and Al-Azzam (2016) said that when constructing an optimal portfolio, the portfolio must include assets which are able to offer a reduction in risk due to their low levels of dynamic correlation, but the effective diversification of risk in relation to investment decision in capital market is still an area of longstanding confusion. This unresolved investor's portfolio choice problem has led to the lack of rigorous effort in the provision of portfolio investment strategy in the capital market and the investor's protection is indirectly affected. In this sense, the financial stability of one asset class has a significant effect on capital market performance. The evidence shows that financial institution are the major institutional investors in many asset classes (He, Kelly, and Manela, 2017) except in (Frijns, Huynh, Tourani-Rad, and Westerholm, 2018) whose consider household as major investors.

\section{Co-movement of Risk and Return}

The co-movement analysis used by various studies on a different geographical region (Marfatia, 2017; Mensi, Hammoudeh, and Kang, 2017; Mimouni, Charfeddine, and Al-Azzam, 2016). Researchers have mentioned significant co-movement between developed markets and emerging markets (Buchanan, English, and Gordon, 2011; Marfatia, 2017), developed and BRICS stock market (Mimouni et al. 2016) and Gulf Cooperation Council countries (Mensi, Hammoudeh, and Kang, 2017). However, the measure does not capture the level of portfolio diversification implication as they measure inter-market (Mensi, Hammoudeh, and Kang, 2017 and Buchanan, English, and Gordon 2011). Therefore, as highlighted in Buchanan, English, and Gordon (2011), it is possible to investigate effects of diversification in capital market investment on different types of asset class and improve the investor's portfolio decision (Mensi, Hammoudeh, Al-Jarrah, Sensoy, \& Kang, 2017). This shows, there is a need to analyze the co-movement of stock return and volatility of multi-assets at the aggregate and sectoral levels.

\section{Conclusion and Future Agenda}

The issue of effective diversification of risk on capital market investment has become an area of interest in the finance literature. Hence, this study points out the need to examine the 
diversification of risk in the capital market through investment in multi-asset class to offer increased diversification potential. Given the assets are of different classes which helpful for understanding the relationship between risky assets and non-risky assets. Further research should examine the diversification of risk through the co-movement on sectoral level. Although most of the previous studies have been focusing on the co-movement of country-level market indices, much less is known at sector levels. Therefore, a deeper understanding of risk and return behavior of such equity indices can help sustain the increasing interest of investors in the industry.

\section{References}

Ahmed, A. D., \& Huo, R. (2018). China-Africa financial markets linkages: Volatility and interdependence. Journal of Policy Modeling, 40(6), 1140-1164. https://doi.org/10.1016/j.jpolmod.2018.05.002

Anand, A., Li, T., Kurosaki, T., \& Kim, Y. S. (2016). Foster-Hart optimal portfolios. Journal of Banking and Finance, 68, 117-130. https://doi.org/10.1016/j.jbankfin.2016.03.011

Bouri, E., Gupta, R., Hosseini, S., \& Lau, C. K. M. (2018). Does global fear predict fear in BRICS stock markets? Evidence from a Bayesian Graphical Structural VAR model. Emerging Markets Review, 34, 124-142. https://doi.org/10.1016/j.ememar.2017.11.004

Cascino, S. (2017). Stock-bond return co-movement and accounting, (2009), 1036-1072. https://doi.org/10.1111/jbfa.12253

Cotter, J., Eyiah-donkor, E., \& Poti, V. (2017). Predictability and diversification benefits of investing in commodity and currency futures. International Review of Financial Analysis, 50, 52-66. https://doi.org/10.1016/j.irfa.2016.12.009

Ehm, C., Kaufmann, C., \& Weber, M. (2014). Volatility inadaptability: Investors care about risk, but cannot cope with volatility. Review of Finance, 18(4), 1387-1423. https://doi.org/10.1093/rof/rft032

Frijns, B., Huynh, T. D., Tourani-Rad, A., \& Westerholm, P. J. (2018). Institutional trading and asset pricing. Journal of Banking \& Finance, 89, 59-77. https://doi.org/10.1016/j.jbankfin.2018.01.018

Hammoudeh, S., Mensi, W., Reboredo, J. C., \& Nguyen, D. K. (2014). Dynamic dependence of the global Islamic equity index with global conventional equity market indices and risk factors. Pacific Basin Finance Journal, 30, 189-206. https://doi.org/10.1016/j.pacfin.2014.10.001

He, Z., Kelly, B., \& Manela, A. (2017). Intermediary asset pricing: New evidence from many asset classes. Journal of Financial Economics, 126(1), 1-35. https://doi.org/10.1016/j.jfineco.2017.08.002

Kim, M. H., \& Sun, L. (2017). Dynamic conditional correlations between Chinese sector returns and the S\&P 500 index: An interpretation based on investment shocks. International Review of Economics and Finance, 48(November 2016), 309-325. https://doi.org/10.1016/j.iref.2016.12.014

Marfatia, H. A. (2017). A fresh look at integration of risks in the international stock markets: A wavelet approach. Review of Financial Economics, 34(1), 33-49. 
INTERNATIONAL JOURNAL OF ACADEMIC RESEARCH IN BUSINESS AND SOCIAL SCIENCES

Vol. 9, No. 11, November, 2019, E-ISSN: 2222-6990 @ 2019 HRMARS

https://doi.org/10.1016/j.rfe.2017.07.003

Markowitz, H. (1952). Portfolio Selection. The Journal OfFinance, 1(1), 77-91. https://doi.org/10.1144/GSL.JGS.1861.017.01-02.11

Mazouz, K., Mohamed, A., \& Saadouni, B. (2016). Stock return comovement around the Dow Jones Islamic Market World Index revisions. Journal of Economic Behavior and Organization, 132, 50-62. https://doi.org/10.1016/j.jebo.2016.05.011

Demirer, M. B. G. C. R. (2016). Is there a role for Islamic bonds in global diversification strategies? Managerial Finance, 42(7). https://doi.org/http://dx.doi.org/10.1108/MF-072015-0189

Mensi, W., Hammoudeh, S., Al-Jarrah, I. M. W., Sensoy, A., \& Kang, S. H. (2017). Dynamic risk spillovers between gold, oil prices and conventional, sustainability and Islamic equity aggregates and sectors with portfolio implications. Energy Economics, 67, 454-475. https://doi.org/10.1016/j.eneco.2017.08.031

Mensi, W., Hammoudeh, S., \& Kang, S. H. (2017). Risk spillovers and portfolio management between developed and BRICS stock markets. North American Journal of Economics and Finance, 41, 133-155. https://doi.org/10.1016/j.najef.2017.03.006

Mimouni, K., Charfeddine, L., \& Al-Azzam, M. (2016). Do oil producing countries offer international diversification benefits? Evidence from GCC countries. Economic Modelling, 57, 263-280. https://doi.org/10.1016/j.econmod.2016.05.001

Podkaminer, E., Tollette, W., \& Siegel, L. (2019). Preparing a Multi-Asset Class Portfolio for Shocks to Economic Growth. The Journal of Portfolio Management, 45(2):106-116. https://doi.org/10.3905/jpm.2018.45.2.106

Sukumaran, A., Gupta, R., \& Jithendranathan, T. (2015). Looking at new markets for international diversification: Frontier markets. International Journal of Managerial Finance, 11(1), 97116. https://doi.org/10.1108/IJMF-05-2013-0057

\section{Corresponding Author}

Aminah Shari, Department of Accounting and Finance, Faculty of Economics and Management, Universiti Putra Malaysia, 43400 UPM, Serdang, Selangor, Malaysia.

Email: aminah83@ums.edu.my 